\title{
Algae as the Sources of Food and the Other Nutrients
}

\author{
Madhu Agrawal* and Teena Agrawal \\ Assistant professor, Banasthali vidhyapeth, India \\ Received: June 15, 2018; Published: June 22, 2018 \\ *Corresponding author: Madhu Agrawal, Assistant professor, Banasthali vidhyapeth, India
}

\begin{abstract}
Algae are the typical eukaryotic organisms, which are at the lower level of the evolution. From them the evolution proceeds out in different directions. They have very diverse ranges of the thallus of the pigments. The chlorophyta are characterised by the formation of the chla A,chl $\mathrm{B}$, and the chl $\mathrm{c}$ and many other kinds of the pigments, theses accessory pigments sometimes makes the hiding of the main pigments and they are charterised by the differ kinds of the Name, theses name are the green algae, blue green algae, yellow algae and the golden algae, diatoms, red algae, brown algae.
\end{abstract}

Keywords: Golden Algae; Diatoms; Red Algae; Brown Algae; Chla A; Chl B

\section{Introduction}

Algae are the typical eukaryotic organisms, which are at the lower level of the evolution. They harbour the very different kinds of the habitat, theses habitat ranges from the small ponds to the large oceans, some of the brown algae as well as the red algae harbours the large oceans of the several meters [1,2]. The nutrient composition of the algae varies from the genera to the genera's. Some of the microalgae are the very good sources of the various kinds of the metabolites of the different nutrient components. From the time immoral a details work has been done on the nutrient composition of the algae, from the differ civilization the algae are used for the various purposes. They are the primary producers of the different ecosystem, some of the ecosystems are the aquatic and the another of them are the terrestrial ecosystem, they are the rich sources of the various kinds of the metabolites of different composition, they have the large proteins, carbohydrates, fats and the vitamins of the several complexes composition [3-6].

In some of the genera's such as the Spirulina and the Dounlliela the cells are the very rich sources of the proteins, similarly another genera are also the very rich and the fine sours of the fatty acids of the various composition, some time the composition of the fatty acids is very similar to the commercial oils of the angiosperm origin [7-15]. oil from the some of the microalgae are the rich sources of the PUFA and they are used as the good sources of the food and feed, in some of the allergies they are used for the treatment of the disorders. The uses of the algae as the food may be other sources of the food, which is more fascinating and more diverse kinds than the existing food of the angiosperm parts of the plants. Most of the algae are the autotrophic and some of the algae are the heterotrophic and they need other kinds of the host of or the nutrition. In biological world the algae are the term which is used for the algae of the lower group and they are typically of the aquatic inhabitant, some of them lies in the soil habitat and they harbours the oceans habitat [16-19].

On the basis of the biomass they have been divided in to the microalgae and the macro algae of the cellular mass, algae are cultivated and used worldwide for the set and types of the cells varies from the nutrition, although the amount of the genera and the amount of the nutrition varies from the cells to the cells. The algae are the rich sources of the proteins, carbohydrates, various kinds of the fatty acids many of them are the rich sources of the polyunsaturated fatty acids of the several complex compositions. In some of the prospects the microalgae are the much more good than the lands plants, they are easy to cultivate and they utilise the less place than the higher trees, the cultural contusions are also not very tough as the higher plants. since they use the sun energy than the green plants very good amount, so they can be very good and the potential sources for the various kinds of the meataobtes which can be the god sources of the biomass. They are very similar to the microbes or the bacteria and the other microbes, so they can be cultivated in a very simple media and the very simple requirements $[20,21]$.

The cultural conditions are not very complexes as the higher plants and the requirements of the conditions is also very simple. However, the biomass can be enhancing and it can be improved by the manipulating the cultural condition and by adding the differ kinds of the catalysts to enhances the condition for the cultures. The lacking of the nitrogen in the medium leads to the formation 
of the rich amount of the protein of the chlorella of the algae. This kind of the cultural manipulation leads to the formation of the lipids about the $85 \%$ than the ordinary media. The enormous kinds of the biodiversity as well as the recent techniques of the genetic engineering lead to the tremendous sources of the different kinds of the metabolites of the algae as the rich sources fog the food for the future utilization. Sometimes the chemical composition of the microalgae is very rich than the traditional plants chemical composition. For examples the biomass and the protein contents of the Spirulina algae is three times much greater than the other higher plants and the protein content of the beef.

Another microalgae the chlorella contains the protein contents, the quality and the quantity of the proteins is very high and rich than the yeast and the soy plants. Miltonic analysed the protein constants of the several genera's of the cyanobacteria and they found that the protein contents are very rich and they are about the 20-30 percent higher than the higher plants. Algae are also the very rich sources of the fibres. The cell wall of the algae is also the very sources of the fibres and fibres contents. polysaccharides. The agar, alginates and the carraginates are also the very rich sources of the fibres and they harbour the fibre industry very well. Oil contents of the microalgae are also very high, and they harbour the rich mass of the 80 percent and in some of the cases the oil contents of the algae is very similar to the biodiesel. Among of all of the fatty acids the PUFA are the very good and the very rich sources of the fatty acids, among them the $\mathrm{w}-3$ are of the particular values. Among them the valuable are the EPA (icoasapentonic acids) and the DHA (docosahexaenoic acids), the GLA are also very valuable in the synthesis of the prostaglandins.

The clinical trial shows that the GLA are the very useful for the treatment of the arthritis and heart diseases obesity, alcoholism, de pressions chizophrenia. Parkinson diseases, alcoholism and the zinc deficiency. Unsaturated fatty acids lower the level of the risk of enhancing the lipids levels of the membranes, thus they lower the level of the lipid associated diseases of the human beings. In this respect the EPA and the GLA are the very useful and they are very effectives. The basic sources of the EPA and the DHA in the fish mass, the fish obtain and synthesis the omega fatty acids form the microalgae from the food chains of the oceans and the seas, the microalgae obtains from the food chains, so the, microalgae can be the potential sources of the synthesis of the fatty acids for the commercial productions. DHA is very valuable for the synthesis of the fatal brains as well as the formation of the retinal tissue of the foetus. Market et al., has developed and patented the two fermentable strains of the microalgae which produces the oil rich in the DHA life's DHA. This oil was produces form the strains which are not genetically change, they were the natural sources and they were approved by the FDA of the USA for the utilization of the infants. V pure is the very valuable algal products, and they are derive from the fatty acids of the omega origin.

\section{Algae as the Sources of the Vitamins and the Mineral}

algae are the rich sources of the vitamin and the minerals, and they can be used as the rich sources of the mineral and the other supplements. Some of the species of the chlorella contains the rich amount of the vitamins, and they can be used as the full sources of the vitamins supplements. Spirulina contains the one third amounts of the Beta carotenes; the quality of the carotenes is also very similar to the carotene of the carrots and the other angiospemic origin. The Spirulina genus is the rich sources of the several kinds of the vitamins E, thiamine, cobalmione, biotin, inositol. Several microalgae produce the Tocopherols in the great amounts. Algae are the rich sources of the several kinds of the minerals of the different compositions. They are used in the animal feed industry.

The Ash contents of the different algae genera varies according, in some of the cases the ash contents of the Cladophora ranges from the 12 percent to the 44 percent's. Some edible algae contain the high amount for the macro algae and the other trace elements. The studies of the microalgae shows that the macro algae and the other microalgae shows the supplements sources' of the minerals and the other elements in addition to the other supplements of the food and he feed and the minerals which are utilised for the other purposes. Algae as the sources of the antioxidants: They are also the very rich sources of the antioxidants and the other matters. Some of the genera's are the ultiseses as the rich sources of the antioxidants.

\section{Conclusion}

overall this is the short information on the algae as the sources of the food and the other supplements. Algae are the potential sources of the several kinds of the mineral and the other supplements and vitamins; they are the rich sources of the several kinds of the macro as well as the microelements. However deep investigation and the research work are needed for the utilization of the algae as the sources of the food and the other resources.

\section{References}

1. Kottelat M, Whitten T (1996) Freshwater biodiversity in Asia with special reference to fish. World Bank technical paper pp. 343.

2. Aguirre J, Riding R (2005) Dasycladalean algal biodiversity compared with global variations in temperature and sea level over the past 350 Myr 20(6): 581-588.

3. Kerswell AP (2006) Global biodiversity patterns of benthic marine algae. Ecology 87(10): 2479-2488.

4. Sherwood AR, Kurihara A, Conklin KY, Sauvage T, Presting GG (2010) The Hawaiian Rhodophyta Biodiversity Survey (2006-2010) a summary of principal findings. BMC plant biology 10(1): 258.

5. Ács É, Szabó K, Tóth B, Kiss KT (2004) Investigation of benthic algal communities especially diatoms of some Hungarian streams in connection with reference conditions of the Water Framework Directives. Acta Botanica Hungarica 46(3-4): 255-278.

6. Naeem S, Li S (1997) Biodiversity enhances ecosystem reliability. Nature 390(6659): 507.

7. Corliss JO, (2002) Biodiversity and biocomplexity of the protists and an overview of their significant roles in maintenance of our biosphere. Acta Protozoologica 41(3): 199-220.

8. Broady PA (1996) Diversity distribution and dispersal of Antarctic terrestrial algae. Biodiversity \& Conservation 5(11): 1307-1335.

9. Wernberg T, Smale DA, Tuya F, Thomsen MS, Langlois Tj, et al. (2013) An extreme climatic event alters marine ecosystem structure in a global biodiversity hotspot. Nature Climate Change 3(1): 78-82. 
10. Worm B, Duffy JE (2003) Biodiversity, productivity and stability in real food webs. Trends in Ecology \& Evolution, 18(12): 628-632.

11. Thajuddin N, Subramanian G (2005) Cyanobacterial biodiversity and potential applications in biotechnology. Current Science 47-57.

12. Muthukumar C, Muralitharan G, Vijayakumar R, Panneerselvam A, Thajuddin $N$ (2007) Cyanobacterial biodiversity from different freshwater ponds of Thanjavur Tamilnadu (India) p. 32.

13. Norton TA, Melkonian M, Andersen RA (1996) Algal biodiversity. Phycologia 35(4): 308-326.

14. Sherwood AR, Kurihara A, Conklin KY, Sauvage T, Presting GG (2010) The Hawaiian Rhodophyta Biodiversity Survey (2006-2010) a summary of principal findings. BMC plant biology 10(1): 258.

15. Ács É, Szabó K, Tóth B, Kiss KT (2004) Investigation of benthic algal communities especially diatoms of some Hungarian streams in connection with reference conditions of the Water Framework Directives. Acta Botanica Hungarica 46(3-4): 255-278.

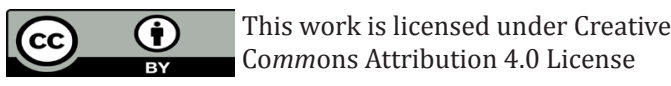

Submission Link: https://biomedres.us/submit-manuscript.php
16. Broady PA (1996) Diversity distribution and dispersal of Antarctic terrestrial algae. Biodiversity \& Conservation 5(11): 1307-1335.

17. Ros MD, MarínMurcia J P, Aboal M (2009) Biodiversity of diatom assemblages in a Mediterranean semiarid stream implications for conservation. Marine and Freshwater Research 60(1): 14-24.

18. Anand N (1998) Indian Freshwater Microalgae. Bishen Singh Mahendra Pal Singh. Dehra Dun, India, p. 94.

19. Desikachary TV, Cyanophyta (1989) Indian Council of Agricultural Research, New Delhi, India.

20. Dwivedi BK, Pandey GC (2002) Physicochemical factors and algal diversity of two ponds (Girija Kund and Maqubara Pond), Faizabad, India. Poll Res 21(3): 361-369

21. Krishnamurthy V (2000) Algae of India and neighbouring countries, Chlorophycota Oxford \& IBH Publishing Co. Pvt Ltd. New Delhi, India.

Assets of Publishing with us
BEMEDICAL
- Global archiving of articles
- Immediate, unrestricted online access
- Rigorous Peer Review Process
- Anttps://biomedres.us/

